\title{
Risk assessment of radioactivity in soils of forest and grassland ecosystems of the Western Ghats, India
}

\author{
P.K. Manigandan ${ }^{1 \star}$ and B. Chandar Shekar ${ }^{2}$ \\ 1 Sai Nath University, Ranchi, India. \\ 2 Kongunadu Arts and Science College (Bharathiar University), Coimbatore, India.
}

Received 16 April 2015 - Accepted 9 July 2015

\begin{abstract}
Naturally occurring radionuclides were investigated in soil samples collected from a tropical rainforest in the Western Ghats, India. For comparison, a number of soil samples from nearby meadows (open grassland) were also studied using gamma-ray spectrometry. Average values of the activity concentration of radionuclides, outdoor gammaray dose rate, annual effective dose equivalent and radiation hazard indices from soil activity were estimated. Significant differences were found between the soils from the forest and meadow sites: the meadow sites contained higher natural radionuclide concentrations than the forest sites. The activity concentration of ${ }^{232} \mathrm{Th}$ and average outdoor gamma-ray dose rates were found to be higher than the global average in both ecosystems, so high gamma radiation appears to affect the Western Ghats environment. Therefore, the radiological risks to the general population from ionizing radiation from the naturally occurring radionuclides in the soil are considered to be significant. However, other radiological hazard indices that were calculated were within acceptable limits.
\end{abstract}

Keywords: radionuclides / Western Ghats / monazite / radiological hazard / cosmic radiation

\section{Introduction}

The natural radioactivity level can vary considerably between soil types, and it is usually determined from the ${ }^{238} \mathrm{U}$, ${ }^{232} \mathrm{Th}$ and ${ }^{40} \mathrm{~K}$ concentrations in the soil (OECD, 1979). Spatial variations in the external gamma-ray dose rate mean that it is essential to measure radionuclide concentrations in soil samples taken from around a particular site of interest rather than solely at the site itself. The external gamma-ray dose varies depending on the concentrations of the natural radionuclides ${ }^{238} \mathrm{U}$ and ${ }^{232} \mathrm{Th}$, their daughter products, and ${ }^{40} \mathrm{~K}$ in the soil, and these, in turn, depend on the local geology (Radhakrishna et al., 1993; Quindos et al., 1994). Previous research indicated that the activity concentration of thorium is high in the region of the Western Ghats, located along the western coast of India, especially around the Nilgiri hill station, due to the presence of monazite sand (Iyengar et al., 1990; Selvasekarapandian et al., 1999; Manigandan and Chandar Shekar, 2014). The external radiation levels from monazite sands in India are higher than those in Brazil, and a high content of thorium and traces of uranium are also present in these areas. These radionuclides may have scattered during igneous, sedimentary and metamorphic cycles of geological evolution, leading to small deposits following certain geological processes. Thus, our study area, in the Western Ghats, India, is in a high background radiation zone, and exposure to external radiation in this area is caused

\footnotetext{
^ pkmgs@yahoo.com
}

by gamma rays emitted by radionuclides in monazite sands that originated in granites and gneisses. Monazite sands contain phosphates of a number of elements, including cerium and radioactive thorium (Mishra, 1993; Sunta et al., 1982).

Exposure to gamma radiation from radioactive materials in a forest ecosystem depends on the geological and geographical conditions, and will be different in different areas. Forest sites differ from meadow sites in several important ways, the main one being that meadow soils are periodically plowed and fertilized, whereas forest ecosystems, being relatively undisturbed, have relatively clear subdivisions between the upper (mainly organic) and lower (mineral) horizons. These horizons differ in several important characteristics, including $\mathrm{pH}$, moisture content, nutrient status and biological activity (Frissel et al., 1990). Meadows are often monocultures, whereas forest ecosystems are species-rich. Anthropogenic activity, particularly application of phosphate fertilizer, significantly increases the radioactivity level of cultivated soil as compared with soil from forests. The cycling of radionuclides is, therefore, much more difficult to understand in forests than in simple meadows. In particular, the great variability found in radioactivity data for the soils, plants and animals in forests makes it difficult for policy-makers to formulate reliable analytical models.

In this study, we aimed to assess the environmental radiation levels in virgin and contaminated soils collected from the Western Ghats. We compared the results with national and global means. The results will be useful baseline data 


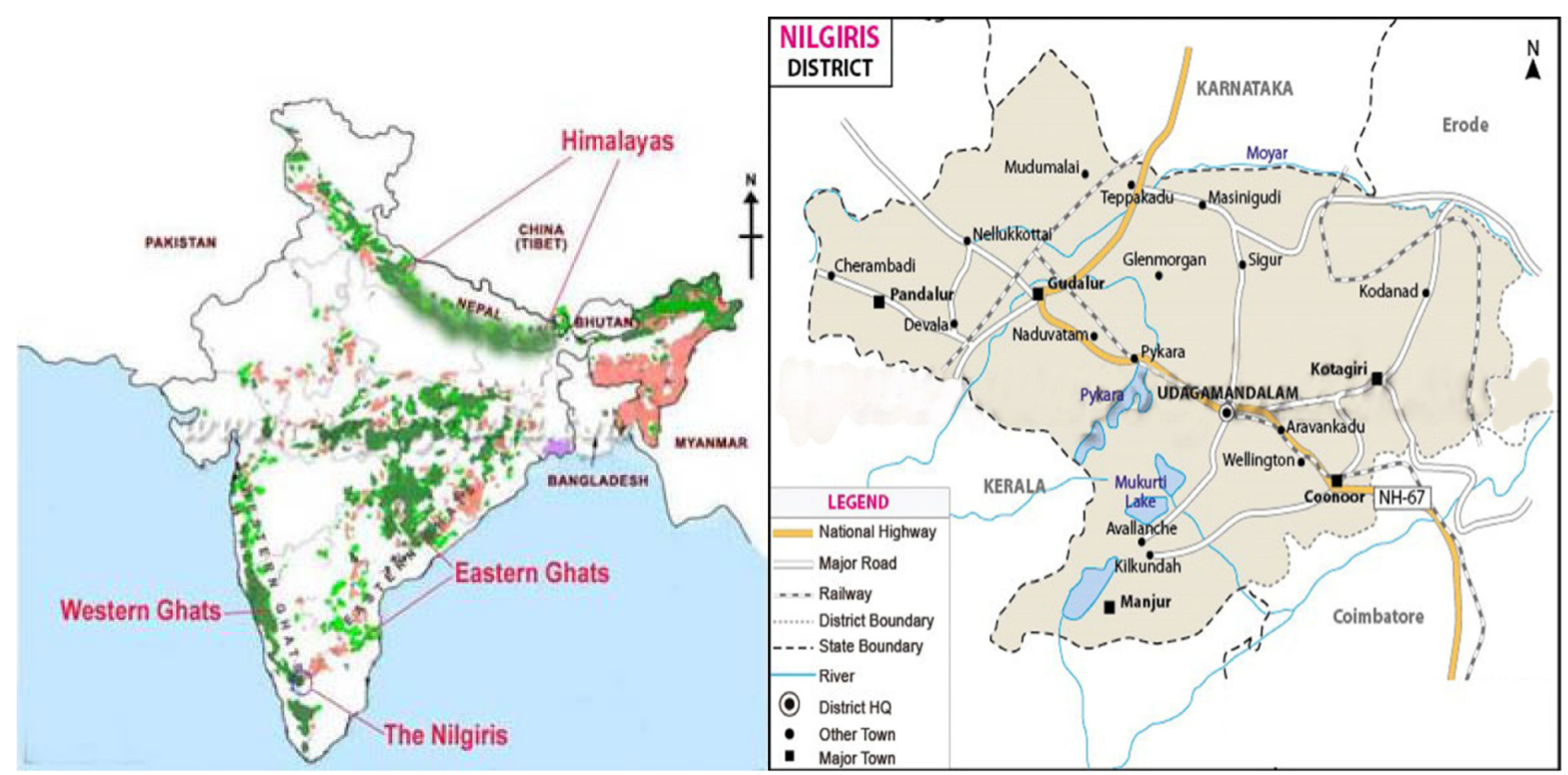

Figure 1. Study area: Nilgiris District.

for natural radioactivity levels in the study area and surrounding region, and will be useful for assessing the radiation doses received by the local population.

\section{Materials and methods}

\subsection{Study area}

The soils analyzed were collected at an elevation ranging between 2000 and $2400 \mathrm{~m}$ the Nilgiri Highlands, Tamil Nadu, South India, which are situated between $11^{\circ} 00^{\prime}$ and $11^{\circ} 30^{\prime} \mathrm{N}$ and between $76^{\circ} 00^{\prime}$ and $77^{\circ} 30^{\prime} \mathrm{E}$. The Nilgiri massif is located at the junction between the Eastern and Western Ghats, and is bounded by abrupt slopes. The study area is shown in Figure 1. The vegetation above $2000 \mathrm{~m}$ in the highlands is a mosaic of high-elevation evergreen forests, called 'shola' locally, and grasslands with different compositions of flora, including C4 grasses (Sukumar et al., 1995; Rajagopalan et al., 1997).

\subsection{Sample collection}

The study area was divided into a 4-km grid and soil samples were collected from forest sites at 15 sampling points in the natural, uncultivated and grass-covered level areas within the grid, conforming with International Atomic Energy Agency recommendations (IAEA, 1989). The 15 sampling points followed a zig-zag pattern. Five 20-cm-deep samples were collected at equal distances along a 1-m circle around the center of each sampling point. This sampling method was used to improve the representativeness of the samples. The position and elevation of each sampling point was determined using a global positioning system. A similar sample collection method was adopted at 25 sampling points from cultivated fields (meadow sites) around Nilgiris District.

\subsection{Sample processing}

The soil samples were transported to the laboratory, and plant roots and other unwanted materials such as grass, stone and biological material were removed. The samples were then dried in an oven at $105{ }^{\circ} \mathrm{C}$ for $12-24 \mathrm{~h}$, ground, and passed through a 2-mm sieve. About $400 \mathrm{~g}$ of dry sample were weighed into a $250-\mathrm{mL}$ plastic container, which was capped and sealed. The container was sealed to ensure that none of the daughter products of uranium and thorium that were produced, particularly radon and thoron, could escape. The prepared samples were stored for 1 month before counting to ensure that equilibrium had been established between radium and its short-lived daughters. Detailed gamma-ray spectrometry analysis was performed on the soil samples (Manigandan and Chandar Shekar, 2014).

\subsection{Activity determination}

The samples were analyzed using a $\mathrm{NaI}(\mathrm{Tl})$ spectrometer coupled with a TNIPCAII Ortec model $8 \mathrm{~K}$ multi-channel analyzer. The ${ }^{232} \mathrm{Th}$-series, ${ }^{238} \mathrm{U}$-series and ${ }^{40} \mathrm{~K}$ activities were estimated, as were the amounts of these radionuclides that would enter the air from the soil. A 3 inch $\times 3$ inch NaI(Tl) detector was used, with adequate lead shielding, which reduced the background by a factor of 95. The energies of interest were found using an International Atomic Energy Agency standard source and the appropriate geometry. RGU-1 (uranium ore), RGTh-1 (thorium ore) and RGk-1 (potassium sulfate) reference sources with an activity of $1065 \mathrm{~Bq}$, $1608 \mathrm{~Bq}$ and $4810 \mathrm{~Bq}$ were used in efficiency calibrations and these standards were obtained from the Radiological Safety Division, Indira Gandhi Centre for Atomic Research (IGCAR), Kalpakkam. The system was calibrated 
Table 1. Statistical summary of ${ }^{238} \mathrm{U},{ }^{232} \mathrm{Th}$ and ${ }^{40} \mathrm{~K}$ activity concentrations in the meadow (reproduced from Manigandan and Chandar Shekar, 2014) and forest soil samples.

\begin{tabular}{|c|c|c|c|c|c|c|}
\hline \multirow{2}{*}{$\begin{array}{l}\text { Ecosystem } \\
\text { Radionuclides }\end{array}$} & \multicolumn{3}{|c|}{ Meadow sites (25 samples) } & \multicolumn{3}{|c|}{ Forest sites (15 samples) } \\
\hline & $\begin{array}{c}{ }^{238} \mathrm{U} \\
\left(\mathrm{Bq} \cdot \mathrm{kg}^{-1}\right)\end{array}$ & $\begin{array}{c}{ }^{232} \mathrm{Th} \\
\left(\mathrm{Bq} \cdot \mathrm{kg}^{-1}\right)\end{array}$ & $\begin{array}{c}{ }^{40} \mathrm{~K} \\
\left(\mathrm{~Bq} \cdot \mathrm{kg}^{-1}\right)\end{array}$ & $\begin{array}{c}{ }^{238} \mathrm{U} \\
\left(\mathrm{Bq} \cdot \mathrm{kg}^{-1}\right)\end{array}$ & $\begin{array}{c}{ }^{232} \mathrm{Th} \\
\left(\mathrm{Bq} \cdot \mathrm{kg}^{-1}\right)\end{array}$ & $\begin{array}{c}{ }^{40} \mathrm{~K} \\
\left(\mathrm{~Bq} \cdot \mathrm{kg}^{-1}\right)\end{array}$ \\
\hline Mean $\pm \sigma$ & $36.3 \pm 17.3$ & $107.8 \pm 50.4$ & $231.9 \pm 84.3$ & $26.3 \pm 9.1$ & $53.6 \pm 10.4$ & $204.1 \pm 30.4$ \\
\hline Standard Error & 3.5 & 10.1 & 15.9 & 2.3 & 2.7 & 7.8 \\
\hline Range & $12.4-85.8$ & $30.3-204.1$ & $83.1-411.6$ & $15.1-4.2$ & $39.2-76.1$ & $127.5-248.1$ \\
\hline $\begin{array}{l}\text { Confidence level } \\
(95.0 \%)\end{array}$ & 0.22 & 0.64 & 1.07 & 0.15 & 0.17 & 0.50 \\
\hline
\end{tabular}

$\sigma=$ Standard deviation

in terms of both the energy response and the counting efficiency. The density of the sample used for the calibration was $1.3 \mathrm{~g} . \mathrm{cm}^{-3}$, which was the same as the mean density of the soil samples analyzed $\left(1.24 \mathrm{~g} . \mathrm{cm}^{-3}\right)$; the detector was very well shielded, and the counting time was $20000 \mathrm{~s}$ for each sample. The concentrations of the radionuclides of interest were determined using the counting spectrum for each sample. The peaks were $1.46 \mathrm{MeV}$ for ${ }^{40} \mathrm{~K}, 1.76 \mathrm{MeV}$ for ${ }^{214} \mathrm{Bi}$ and $2.614 \mathrm{MeV}$ for ${ }^{208} \mathrm{Tl}$, for evaluation of the ${ }^{40} \mathrm{~K},{ }^{238} \mathrm{U}$ series and ${ }^{232} \mathrm{Th}$-series activities, respectively. The Below Detectable Limits (BDL) was $18.9 \mathrm{~Bq} \cdot \mathrm{kg}^{-1}$ for ${ }^{40} \mathrm{~K}, 2.03 \mathrm{~Bq} \cdot \mathrm{kg}^{-1}$ for ${ }^{214} \mathrm{Bi}$ and $4.7 \mathrm{~Bq} \cdot \mathrm{kg}^{-1}$ for ${ }^{208} \mathrm{Tl}$, and they were estimated using the formula suggested by Kpelgo et al. (2011). The gamma-ray spectrum activities for each soil sample were analyzed using dedicated software, and references were chosen to achieve sufficient discrimination (Manigandan and Chandar Shekar, 2014).

In addition to the gamma-ray spectrometric analysis, a low-level survey environmental radiation dosimeter (type ER 705; Nucleonic System PVT Ltd., Hyderabad, India) was used to measure the ambient radiation levels in the study areas directly associated with radionuclide activity concentrations in the samples and cosmic rays. The dosimeter had a halogenquenched Geiger-Müller detector (Ind. lnc., USA) powered by a rechargeable battery, and was designed to read the exposure rate at two levels, $0.1 \mu \mathrm{R} \cdot \mathrm{h}^{-1}$ and $1 \mu \mathrm{R} \cdot \mathrm{h}^{-1}$. The dosimeter was calibrated using a standard source before use. Outdoor terrestrial gamma dose rates were measured at $1 \mathrm{~m}$ above the ground by a portable digital ERD at all the sampling sites. A total of five readings were recorded at each spot and the average taken (Manigandan and Chandar Shekar, 2014).

\section{Results and discussion}

The ${ }^{238} \mathrm{U},{ }^{232} \mathrm{Th}$ and ${ }^{40} \mathrm{~K}$ activity concentrations were determined for the two soil sample types measured, and the mean activities, the standard deviations and activity ranges are shown in Table 1.

It can be seen from Table 1 that the mean ${ }^{232} \mathrm{Th}$ activity concentration in the meadow samples was twice that in the forest samples, and that the ${ }^{232} \mathrm{Th}$ activity concentrations in both ecosystems were much higher than the global mean, 45 Bq. $\mathrm{kg}^{-1}$ (UNSCEAR, 2008).
The relatively high ${ }^{232} \mathrm{Th}$ activity concentrations at both sites were caused by the presence of monazite. Valithan et al. (1994) reported that deposits of monazite on the coastal areas of Kerala and Tamil Nadu formed due to the weathering of rocks in the Western Ghats. Monazite sands consist of phosphate minerals with elements such as cerium, and occur as small brown crystals in the Kerala sands. These monazite sands are mined for cerium and radioactive thorium oxide. The sands originate in the granites and gneisses of the Western Ghats, and are transported to the coast by more than 47 streams along the Kerala coastline.

However, the mean ${ }^{238} \mathrm{U}$ and ${ }^{40} \mathrm{~K}$ activity concentrations were lower than the global means, $32 \mathrm{~Bq} \cdot \mathrm{kg}^{-1}$ and 412 Bq. $\mathrm{kg}^{-1}$, respectively (UNSCEAR, 2008).

There were no major differences in the activity concentrations in the virgin and agricultural soils in the study area. However, slightly higher activity concentrations were measured in the meadow samples, which would have been caused by agricultural activities redistributing the radionuclides in the soil profile.

\subsection{Dose calculations and field measurement}

\subsubsection{Absorbed and observed dose rates}

The absorbed dose rate (D) due to gamma radiation in air at $1 \mathrm{~m}$ above the ground surface for uniform distribution of the naturally occurring radionuclides was calculated, and in situ measurements were also carried out site by site using an environmental radiation dosimeter.

The mean ${ }^{238} \mathrm{U},{ }^{232} \mathrm{Th}$ and ${ }^{40} \mathrm{~K}$ activity concentrations were converted into dose rates using conversion factors provided by UNSCEAR (2008), as shown in equation (1):

$$
\mathrm{D}=\left(0.462 C_{U}+0.604 C_{T h}+0.0417 C_{K}\right) \mathrm{nGy} \cdot \mathrm{h}^{-1}
$$

where $D$ is the calculated absorbed dose rate $\left(\mathrm{nGy}^{-1} \mathrm{~h}^{-1}\right)$ and $C_{U}, C_{T h}$ and $C_{K}$ are the ${ }^{238} \mathrm{U},{ }^{232} \mathrm{Th}$ and ${ }^{40} \mathrm{~K}$ activities (Bq. $\mathrm{kg}^{-1}$ ) in the soil samples, respectively. It can be seen from Table 2 that the ${ }^{232} \mathrm{Th}$-series contributed $71 \%$ of the total gamma-ray dose in both ecosystems, whereas the ${ }^{238} \mathrm{U}$-series and ${ }^{40} \mathrm{~K}$ contributed $19 \%$ and $10 \%$ of the total gamma-ray dose.

The forest site calculated absorbed dose rates ranged from $38.9 \mathrm{nGy} \cdot \mathrm{h}^{-1}$ to $76.7 \mathrm{nGy} \cdot \mathrm{h}^{-1}$, and the mean was $53.0 \pm$ 
Table 2. Statistical summary of dose rates for the two ecosystems studied.

\begin{tabular}{|c|c|c|c|c|c|c|}
\hline \multirow{2}{*}{$\begin{array}{l}\text { Ecosystem } \\
\text { Dose rate }\end{array}$} & \multicolumn{3}{|c|}{ Meadow sites (25 samples) } & \multicolumn{3}{|c|}{ Forest sites (15 samples) } \\
\hline & $\begin{array}{c}\text { Calculated } \\
\text { absorbed dose } \\
\left(\mathrm{nGy} \cdot \mathrm{h}^{-1}\right)\end{array}$ & $\begin{array}{l}\text { Observed } \\
\text { dose } \\
\left(\mathrm{nGy}^{-1} \mathrm{~h}^{-1}\right)\end{array}$ & $\begin{array}{c}\text { Annual effective } \\
\text { dose equivalent } \\
(\mu \mathrm{Sv})\end{array}$ & $\begin{array}{c}\text { Calculated } \\
\text { absorbed dose } \\
\left(\mathrm{nGy}^{-1} \mathrm{~h}^{-1}\right)\end{array}$ & $\begin{array}{l}\text { Observed dose } \\
\left(\mathrm{nGy} \cdot \mathrm{h}^{-1}\right)\end{array}$ & $\begin{array}{c}\text { Annual effective } \\
\text { dose equivalent } \\
(\mu \mathrm{Sv})\end{array}$ \\
\hline Mean $\pm \sigma$ & $91.5 \pm 34.0$ & $133.3 \pm 183.3$ & $112.3 \pm 41.7$ & $53.0 \pm 11.4$ & $97.0 \pm 13.0$ & $65.0 \pm 13.8$ \\
\hline Standard Error & 6.8 & 36.6 & 8.3 & 2.9 & 3.4 & 3.6 \\
\hline Range & $39.1-153.4$ & 20.7-992.7 & $48.0-203.8$ & $38.9-76.7$ & $83.0-123.8$ & $47.8-94.1$ \\
\hline $\begin{array}{l}\text { Confidence level } \\
(95.0 \%)\end{array}$ & 0.43 & 2.32 & 0.53 & 0.19 & 0.21 & 0.23 \\
\hline
\end{tabular}

$\sigma=$ Standard deviation.

$11.4 \mathrm{nGy} \cdot \mathrm{h}^{-1}$. The meadow site calculated absorbed dose rates ranged from $39.11 \mathrm{nGy} \cdot \mathrm{h}^{-1}$ to $153.40 \mathrm{nGy} \cdot \mathrm{h}^{-1}$, and the mean was $91.5 \pm 34.0 \mathrm{nGy} \cdot \mathrm{h}^{-1}$. The calculated absorbed dose rate in both ecosystems exceeded the global mean of $56 \mathrm{nGy} \cdot \mathrm{h}^{-1}$ (UNSCEAR, 2008).

The outdoor gamma-ray dose rates measured $1 \mathrm{~m}$ above the ground using a portable digital environmental radiation dosimeter are presented in Table 2. The mean global outdoor gamma-ray dose rate was found to be $60 \mathrm{nGy} \cdot \mathrm{h}^{-1}$, and the range was found to be $10-200 \mathrm{nGy} \cdot \mathrm{h}^{-1}$ (Taskin et al., 2009). The mean observed gamma-ray dose rates in the study area were $97.0 \mathrm{nGy} \cdot \mathrm{h}^{-1}$ at the forest sites and $133.3 \mathrm{nGy} \cdot \mathrm{h}^{-1}$ at the meadow sites, which are both much higher than the global mean. The gamma radiation level is directly associated with the radionuclide activity concentrations in the samples and with cosmic rays (Taskin et al., 2009). The observed gammaray dose rate was more than $50 \%$ of the dose calculated from the soil activities, and the difference would have been caused by the cosmic radiation contribution to the total dose in the Western Ghats environment, which is $2400 \mathrm{~m}$ above sea level.

\subsubsection{Annual effective dose equivalents}

The absorbed dose to effective dose conversion coefficient (0.7 Sv/Gy) and outdoor occupancy factor (0.2), which have been proposed by UNSCEAR (2008), were used to estimate the annual effective dose rates, as shown in equation (2):

$$
\begin{aligned}
& \text { Effective dose rate (Outdoor) }(\mu S v / y)= \\
& \qquad D(n G y / h) \times 8760 h \times 0.7 S v / G y \times 0.2 \times 10^{-3} .
\end{aligned}
$$

The mean outdoor annual effective dose equivalents calculated for the samples are shown in Table 2. The mean outdoor annual effective dose equivalent for the forest sites was $65.0 \pm$ $13.8 \mu \mathrm{Sv}$, which is lower than the global mean value of $70 \mu \mathrm{Sv}$ per year for outdoors (Orgun et al., 2007). However, the mean outdoor annual effective dose equivalent for the meadow sites was $112.3 \pm 41.7 \mu \mathrm{Sv}$, which is much higher than the global mean, and this may be attributed to the higher ${ }^{232} \mathrm{Th}$ activity concentrations found in the soil from the meadow sites. Even though the outdoor annual effective dose equivalents for the samples from the meadow sites were much higher than the global mean value, this was not significant from the radiological hazard point of view.

\subsection{Radiation hazard indices}

A common radiological index, called the radium equivalent activity $\left(\mathrm{Ra}_{\mathrm{eq}}\right)$, is used to represent the ${ }^{238} \mathrm{U},{ }^{232} \mathrm{Th}$ and ${ }^{40} \mathrm{~K}$ activities as a single quantity. $\mathrm{Ra}_{\mathrm{eq}}$ is calculated using equation (3) (Beretka and Mathew, 1985):

$$
R a_{e q}(B q / k g)=\left(C_{U}+1.43 C_{T h}+0.077 C_{K}\right) \ldots \ldots
$$

where $C_{U}, C_{T h}$ and $C_{K}$ are defined as in equation (1) above.

Another radiation hazard index, called the representative level index, $\mathrm{I}_{\gamma \mathrm{r}}$, is defined using equation (4) (Ahmed and El-Arabi, 2005):

$$
\mathrm{I}_{\gamma \mathrm{r}}=\frac{1}{150 \mathrm{~Bq} / \mathrm{kg}} C_{U}+\frac{1}{100 \mathrm{~Bq} / \mathrm{kg}} C_{T H}+\frac{1}{1500 \mathrm{~Bq} / \mathrm{kg}} C_{K} \ldots \ldots .
$$

where $C_{U}, C_{T h}$ and $C_{K}$ are defined as in equation (1).

The $\mathrm{Ra}_{\mathrm{eq}}$ and $\mathrm{I}_{\gamma \mathrm{r}}$ values for the samples analyzed in this work are shown in Table 3.

Based on the annual external dose of $1.5 \mathrm{mGy}$, activity limits in terms of $\mathrm{Ra}_{\mathrm{eq}}$ and $\mathrm{I}_{\gamma \mathrm{r}}$ are $370 \mathrm{~Bq} \cdot \mathrm{kg}^{-1}$ and 1 , respectively, for the safe use of soil products. It was observed that the $\mathrm{Ra}_{\mathrm{eq}}$ values in the soils we analyzed were lower than the maximum value allowed, $370 \mathrm{~Bq} \cdot \mathrm{kg}^{-1}$ (Beretka and Mathew, 1985). The $\mathrm{Ra}_{\mathrm{eq}}$ values were much higher for the meadow sites than for the forest sites, mainly because of the use of fertilizers, which are rich in phosphates, on the meadow sites for agricultural purposes (Ahmed and El-Arabi, 2005). Phosphate rocks contain significant concentrations of $\mathrm{U}, \mathrm{Th}, \mathrm{Ra}$, and their decay products (Skorovarov et al., 2000).

The $I_{\gamma \mathrm{r}}$ values for the samples analyzed in this study are shown in Table 3 . The mean $\mathrm{I}_{\gamma \mathrm{r}}$ value for the meadow samples exceeded the upper limit (one), but the forest samples did not exceed the limit.

\subsection{Comparison of the activity concentrations with those found in similar studies}

The ${ }^{238} \mathrm{U},{ }^{232} \mathrm{Th}$ and ${ }^{40} \mathrm{~K}$ activity concentrations, and $\mathrm{Ra}_{\mathrm{eq}}$, and $\mathrm{I}_{\gamma \mathrm{r}}$ for the samples from the forest and meadow were compared with the values found in similar studies in other countries, and the results are summarized in Table 4.

According to UNSCEAR (2008), the global ${ }^{232}$ Th activity concentration range is $7-50 \mathrm{~Bq} \cdot \mathrm{kg}^{-1}$ (mean $45 \mathrm{~Bq} \cdot \mathrm{kg}^{-1}$ ). 
Table 3. Statistical summary of the radium equivalent activity $\left(\mathrm{Ra}_{\mathrm{eq}}\right)$ and the representative level index $\left(\mathrm{I}_{\gamma \mathrm{r}}\right)$ in the meadow and forest samples.

\begin{tabular}{lcccc}
\hline Ecosystem & \multicolumn{2}{c}{ Meadow sites } & \multicolumn{2}{c}{ Forest sites } \\
\hline Dose rate & $\mathrm{Ra}_{\mathrm{eq}}\left(\mathrm{Bq} \cdot \mathrm{kg}^{-1}\right)$ & $\mathrm{I}_{\gamma \mathrm{r}}$ & $\mathrm{Ra}_{\mathrm{eq}}\left({\left.\mathrm{Bq} \cdot \mathrm{kg}^{-1}\right)}^{-1}\right.$ & $\mathrm{I}_{\gamma \mathrm{r}}$ \\
Mean $\pm \sigma$ & $208.3 \pm 79.4$ & $1.47 \pm 0.6$ & $118.6 \pm 25.3$ & $0.85 \pm 0.2$ \\
Standard Error & 15.9 & 0.11 & 6.5 & 0.05 \\
Median & 188.4 & 1.4 & 106.4 & 0.76 \\
Range & $86.93-379.22$ & $0.61-2.69$ & $86.44-172.08$ & $0.63-1.22$ \\
Confidence level $(95.0 \%)$ & 1.01 & 0.007 & 0.42 & 0.003 \\
\hline
\end{tabular}

$\sigma=$ Standard deviation

Table 4. Comparison of the ${ }^{238} \mathrm{U},{ }^{232} \mathrm{Th}$ and ${ }^{40} \mathrm{~K}$ activity concentrations, radium equivalent activity $\left(\mathrm{Ra}_{\mathrm{eq}}\right)$ values, and representative level index $\left(\mathrm{I}_{\gamma \mathrm{r}}\right)$ values found in soil and fertilizer samples in this and other studies.

\begin{tabular}{|c|c|c|c|c|c|c|c|}
\hline \multirow{2}{*}{ Country } & \multirow{2}{*}{ Ecosystem } & \multicolumn{3}{|c|}{ Activity $\left(\mathrm{Bq} \cdot \mathrm{kg}^{-1}\right)$} & \multirow{2}{*}{$\begin{array}{c}\mathbf{R a}_{\mathrm{eq}} \\
\left(\mathrm{Bq} \cdot \mathrm{kg}^{-1}\right)\end{array}$} & \multirow{2}{*}{$\mathbf{I}_{\gamma \mathbf{r}}$} & \multirow{2}{*}{ Reference } \\
\hline & & ${ }^{238} \mathrm{U}$ & ${ }^{232} \mathrm{Th}$ & ${ }^{40} \mathrm{~K}$ & & & \\
\hline \multirow{2}{*}{ India } & Virgin soil & 26.26 & 53.61 & 231.93 & 118.6 & 1.47 & \multirow{2}{*}{ This study } \\
\hline & Agri soil & 36.31 & 107.7 & 231.93 & 208.28 & 0.85 & \\
\hline \multirow{2}{*}{ Algeria } & Virgin soil & 47.01 & 43 & 329 & 132 & 0.95 & \multirow{2}{*}{ Wassila et al., 2011} \\
\hline & Agri soil & 53.2 & 50.03 & 311 & 154 & 1 & \\
\hline \multirow{2}{*}{ Brazil } & Virgin soil & 1.69 & 5.32 & 34.15 & 12 & 0.1 & \multirow{2}{*}{ Becegato et al., 2008} \\
\hline & Agri soil & 10.22 & 7.27 & 54.75 & 24.8 & 0.2 & \\
\hline \multirow{2}{*}{ Egypt } & Virgin soil & 13.7 & 12.3 & 1233 & 126.2 & 1.04 & \multirow{2}{*}{ Ahmed and El-Arabi, 2005} \\
\hline & Agri soil & 366 & 66.7 & 4 & 461.7 & 3.1 & \\
\hline \multirow{2}{*}{ Pakistan } & Virgin soil & 27.39 & 31.16 & 602.77 & 142.71 & 1.02 & \multirow{2}{*}{ Akhtar et al., 2005} \\
\hline & Agri soil & 51.96 & 42.48 & 847.22 & 233.04 & 1.75 & \\
\hline
\end{tabular}

*Agri Soil: Agricultural Soil.

The measured ${ }^{232}$ Th activity concentrations in the study area, for both forest and meadow soils, were between 1.5 and 2.5 times higher than the global mean.

The measured ${ }^{238} \mathrm{U}$ and ${ }^{40} \mathrm{~K}$ concentrations in the soil samples from the forest and meadow sites were within the global range, but the soils from the meadow sites contained higher concentrations than the forest sites.

As shown in Table 4, the radioactivity found in forest and meadow soils varies from country to country. It is important to note that the values shown are not representative values for the countries mentioned, but only for the regions in which the samples were collected.

\section{Conclusions}

The radioactive concentrations in soil samples from forest and meadow sites in the Western Ghats, India, were measured using a gamma-ray spectrometry technique. The naturally occurring radionuclide activity concentrations in the soil samples were within the usual global ranges (UNSCEAR, 2008), but the ${ }^{232} \mathrm{Th}$ activity concentrations were at the higher end of the global range. The naturally occurring radionuclide concentrations were much higher in the meadow samples than in the soil samples. Variations in the activity levels in the forest soil samples were within the activity values measured around the world, but this was not the case for the meadow soil samples. The mean outdoor terrestrial gamma-ray dose rate was higher than the global mean, so the Western Ghats region should be classified as having above the global average background radiation. It should also be noted that the calculated activity utilization index from the meadow sites was also found to exceed the recommended safe limit values. This implies that the inhabitants of the meadow sites are subjected to a significantly higher radiation exposure than the corresponding exposure levels reported in other areas worldwide. Despite this, all of the other calculated radiological hazard indices were within acceptable limits, indicating that the soils in this area can be used safely.

\section{References}

Ahmed N.K., El-Arabi A.G.M. (2005) Natural radioactivity in farm soil and phosphate fertilizer and its environmental implications in Qena governorate, Upper Egypt, J. Environ. Radioact. 84, 51-64.

Akhtar N., Tufai M., Ashraf M. (2005) Natural environmental radioactivity and estimation of radiation exposure from saline soils, Int. J. Environ. Sci. Technol. 1, 279-285.

Becegato V.A., Ferreira F.J., Machado F. (2008) Concentration of radioactivity elements derived from Phosphate fertilizers in cultivated soils, Braz. Arch. Biol. Technol. 51, 1255-1266.

Beretka J., Mathew P.J. (1985) Natural radioactivity of Australian building materials, industrial wastes and by products, Health Phys. 48, 87-95.

Frissel M.J., Noordijk K.H., Van Bergejik K.E. (1990) The impact of extreme environmental condition, as occurring in natural ecosystem's on the soil to plant transfer of radionuclides. In: Transfer of radionuclides in natural and semi-natural environments, pp. 40-47. Elsevier, London and New York. 
IAEA (1989) Measurement of Radionuclides in Food and Environment, IAEA Technical Report Series No. 295, p. 169. IAEA, Vienna.

Iyengar M.A.R., Ganapathy S., Kannan V., Rajan M.P., Rajaram S. (1990) Procedure Manual. In: Workshop on Environmental Radioactivity, Kaiga, India, pp. 16-18.

Kpelgo D.O., Lawluvi H., Faanu A., Awudu A.R., Deatanyah P., Wotorchi S.G. (2011) Natural radioactivity and its associated radiological hazards in Ghanaian cement, Research Journal of Environment and Earth Science 3 (2), 160-166.

Manigandan P.K., Chandar Sekar B. (2014) Evaluation of radionuclides in the terrestrial environment of Western Ghats, J. Radiat. Res. Appl. Sci. 7, 310-316.

Mishra U.C. (1993) Exposure due to the high natural radiation and radioactive springs around the world. In: Proceedings of the International conference on high-level radiation areas (Ramsar) Iran, 1990, p. 29. IAEA publication series, Vienna.

OECD Nuclear Agency Energy (1979) Exposure to radiation from natural radioactivity in building materials. NEA, OECD, Paris.

Orgun Y., Altinsoy N., Sahin S.Y., Gungor Y., Gultekin A.H., Karaham G., Karaak Z. (2007) Natural and anthropogenic radionuclides in rocks and beach sands from Ezine region (canakkale), Western Anatolia, Turkey, Appl. Radiat. Isotopes 65 , 739-747.

Quindos L.S., Fernandez P.I., Soto J., Rodenas C., Gomez J. (1994) Natural Radioactivity in Spanish soils, Health Phys. 66, 194-200.

Radhakrishna A.P., Somashekarappa H.M., Narayana Y., Siddappa K.A (1993) New Natural Background Radiation area on the south coast of India, Health Phys. 65, 390-395.

Rajagopalan G., Sukumar R., Ramesh R., Pant R.K. (1997) Late Quaternary vegetational and climatic changes from tropical peats in southern India - An extended record up to 40,000 years BP, Curr. Sci. 73, 60-63.

Selvasekarapandian S., Muguntha Manikandan N., Sivakumar R. (1999) Gamma radiation dose from radionuclides in soil samples of Udagamandalam in India, Radiat. Prot. Dosim. 82, 225-228.

Skorovarov J.I., Rusin L.I., Lomonsov A.V., Chaforian H., Hashemi A., Novaseqhi H. (2000) Development of uranium extraction technology from phosphoric acid solutions with extract. In: Proceedings of International conference on uranium extraction from soil, Vol. 217, pp. 106-113.

Sukumar R., Suresh H.S., Ramesh R. (1995) Climate change and its impact on tropical montane ecosystems in southern India, J. Biogeogr. 22, 533-536.

Sunta C.M., David M., Abani M.C., Basu A.S., Nambi K.S.V. (1982) Analysis of dosimetry data of high natural radioactivity areas of southwest coast of India. In: The Natural Radiation Environment, Wiley Eastern, Bombay/New Delhi, (K.G. Vohra et al., Eds.), pp. 35-42.

Taskin H., Karavus M., Topuzoglu A., Hindiroglu S., Karahan G. (2009) Radionuclide concentrations in soil and lifetime cancer risk due to the gamma radioactivity in Kirklareli, Turkey, J. Environ. Radioact. 100, 49-53.

UNSCEAR (2008) Sources and biological effects of ionizing radiation, Report to general assembly with scientific annexes. United Nations, New York.

Valithan M.S., Kartha C.C., Nair C.C., Shivakumar K., Eapan T.T. (1994) Geochemical basis of tropical endomyocardial fibrosis, Curr. Sci. 67 (2), 99-104.

Wassila B., Boucenna A. (2011) The radioactivity measurements in soils and fertilizers using gamma spectrometry technique, J. Environ. Radioact. 102, 336-339.

Cite this article as: P.K. Manigandan, B. Chandar Shekar. Risk assessment of radioactivity in soils of forest and grassland ecosystems of the Western Ghats, India. Radioprotection 50(4), 259-264 (2015). 